\title{
Bioavailability of sinking organic matter in the Blanes canyon and the adjacent open slope (NW Mediterranean Sea)
}

\author{
P. Lopez-Fernandez ${ }^{1}$, S. Bianchelli ${ }^{2}$, A. Pusceddu ${ }^{2}$, A. Calafat ${ }^{1}$, A. Sanchez-Vidal ${ }^{1}$, and R. Danovaro ${ }^{2}$ \\ ${ }^{1}$ GRC Geociències Marines, Dept. d'Estratigrafia, Paleontologia i Geociències Marines, Universitat de Barcelona, \\ 08028 Barcelona, Spain \\ ${ }^{2}$ Dipartimento di Scienze della Vita e dell'Ambiente, Università Politecnica delle Marche, Via Brecce Bianche, \\ 60131 Ancona, Italy
}

Correspondence to: A. Calafat (antonicalafat@ub.edu)

Received: 30 November 2012 - Published in Biogeosciences Discuss.: 17 December 2012

Revised: 22 April 2013 - Accepted: 23 April 2013 - Published: 23 May 2013

\begin{abstract}
Submarine canyons are sites of intense energy and material exchange between the shelf and the deep adjacent basins. To test the hypothesis that active submarine canyons represent preferential conduits of available food for the deepsea benthos, two mooring lines were deployed at $1200 \mathrm{~m}$ depth from November 2008 to November 2009 inside the Blanes canyon and on the adjacent open slope (Catalan Margin, NW Mediterranean Sea). We investigated the fluxes, biochemical composition and food quality of sinking organic carbon (OC). OC fluxes in the canyon and the open slope varied among sampling periods, though not consistently in the two sites. In particular, while in the open slope the highest OC fluxes were observed in August 2009, in the canyon the highest OC fluxes occurred in April-May 2009. For almost the entire study period, the OC fluxes in the canyon were significantly higher than those in the open slope, whereas OC contents of sinking particles collected in the open slope were consistently higher than those in the canyon. This result confirms that submarine canyons are effective conveyors of OC to the deep sea. Particles transferred to the deep sea floor through the canyons are predominantly of inorganic origin, significantly higher than that reaching the open slope at a similar water depth. Using multivariate statistical tests, two major clusters of sampling periods were identified: one in the canyon that grouped trap samples collected in December 2008, concurrently with the occurrence of a major storm at the sea surface, and associated with increased fluxes of nutritionally available particles from the upper shelf. Another cluster grouped samples from both the canyon and the open slope collected in March 2009, concurrently with the occur-
\end{abstract}

rence of the seasonal phytoplankton bloom at the sea surface, and associated with increased fluxes of total phytopigments. Our results confirm the key ecological role of submarine canyons for the functioning of deep-sea ecosystems, and highlight the importance of canyons in linking episodic storms and primary production occurring at the sea surface to the deep sea floor.

\section{Introduction}

Continental margins are the edges of continents and represent a zone of strong interactions between the continent, the open ocean, and the atmosphere (Weaver at al., 2004). These interactions drive margin's hydrodynamic conditions, which in turn control the dispersal of particulate matter fluxes on the shelf and towards the open sea (Levin and Dayton, 2009). Many previous investigations have shown that continental margins may represent a reservoir of particulate organic matter (often derived from river discharge) which, while transported downslope, represents a key food source for the benthos (Walsh, 1991). Organic carbon (OC) transport to the deep sea is mediated through vertical fluxes of particles, which in turn are influenced by the general climate (Smith et al., 2009), local hydrodynamic conditions (Bonnin et al., 2008) and the presence of different benthic habitats (Pusceddu et al., 2010a). Among these, the submarine canyons indent the continental margins all over the world (Harris and Whiteway, 2011) representing the more intense zone of exchange between the upper continental slope and 
bathyal-to-hadal depths. Submarine canyons may act as a major forced conduit of material to the deep sea (Canals et al., 2006).

A recent investigation carried out along the Mediterranean Sea pinpointed that not all submarine canyons are active conveyors of material to the deep adjacent basin nor are they characterized by significant differences in sedimentary organic matter content and biochemical composition when compared with the adjacent open slopes at similar depths (Pusceddu et al., 2010a). Basically, such lack of consistency can be ascribed to a recurrently missing temporal (seasonal) replication of the data. It is indeed most likely that the input of particulate organic material to the ocean's interior through canyons can be seasonal (e.g., Fabres et al., 2008), with the highest peaks associated with phytoplankton blooms in the upper layers of the water column (Pasqual et al., 2011) or with episodic events, including storms (Palanques et al., 2008; Sanchez-Vidal et al., 2012) and dense shelf water cascading (Tesi et al., 2008; Pasqual et al., 2010; Pusceddu et al., $2010 \mathrm{~b}$ ). In addition, the chemical composition of organic particles changes during sinking because of the consumption by heterotrophic plankton (including prokaryotes) (Hedges et al., 2001). It has indeed been estimated that about $10 \%$ of the primary production falls to a depth of $400 \mathrm{~m}$, whereas only about $1 \%$ reaches $5000 \mathrm{~m}$ (Murray, 1992). This, traditionally, has led most deep-sea ecologists to conceive the deep sea as "nutritionally deprived" environment, missing local primary productivity and being fuelled by very low amounts of nutritionally poor organic particles (Gage and Tyler, 1991; Druffel and Robinson, 1999).

In recent years, the debate about the food limitation of the deep-sea benthos has continued and led to less conservative theories (Smith et al, 2008; Glover et al., 2010; Soetaert and van Oevelen, 2010). This has been mostly due to the fact that several studies have pointed out that the total amount of organic matter is not fully representative of the food quality of particles (Grémare et al., 1998; Misic and CovazziHarrigue, 2008; Pusceddu et al., 2009). Total OC is indeed composed of a biopolymeric fraction, made of biopolymers (including protein, carbohydrate and lipids) of relevance for heterotrophic nutrition (Fabiano and Pusceddu, 1998) and a complex/geo-polymeric fraction, adhered to inorganic particles and mostly refractory to consumption (Mayer, 2004; Grémare et al., 2002; Pusceddu et al., 2009). Early studies indeed demonstrated that among biopolymeric compounds, total proteins and lipids often explain the largest proportion of variations in the macro- and meiofauna growth (Grémare et al., 1997, 1998). Moreover, the whole biopolymeric fraction of suspended particles cannot be rapidly digested by metazoan consumers, as, generally, less than $15-50 \%$ of particulate organic $\mathrm{C}$ is enzymatically digestible (Grémare et al., 2003, 2005; Pusceddu et al., 2003; Dell' Anno et al., 2013).

To our best knowledge, information about the digestible fraction of sinking organic particles towards the deep sea is practically nonexistent. Indirect estimates have been made based on sedimentary data (Dell'Anno et al., 2000; Grémare et al., 2005; Mayer et al., 1995; Vandeweile et al., 2009), but direct measures on trap samples are not yet available.

In this study, we investigated the biochemical composition of particulate organic matter and its bioavailability to benthic consumers (using an enzymatic approach enabling the determination of the potentially digestible fraction), settling down along the water column during one year-long (November 2008-November 2009) intensive (weekly) sampling activity carried out comparatively inside the Blanes canyon and on its adjacent open slope (Catalan Margin, NW Mediterranean Sea), at the same water depth.

\section{Material and methods}

\subsection{The study area}

The Blanes canyon (Fig. 1) is oriented in $\mathrm{N}-\mathrm{S}$ direction and located in the northern Catalan margin (NW Mediterranean Sea). The Catalan margin is characterized by very complicated seafloor topography, showing a narrow continental shelf deeply incised by other canyons (Amblas et al., 2006). The head of Blanes canyon is less than $4 \mathrm{~km}$ from the coast, at $60 \mathrm{~m}$ depth. The Tordera River mouth is located near the head of the canyon. Occasionally, its main discharge corresponds to short-lived episodic floods (Rovira and Batalla, 2006). The canyon has a V-shaped cross section in the shoreward region characterized by a strong erosion, and a U-shaped cross section collecting sediment deposition from upper areas more offshore (Lastras et al., 2011; Fig. 1). Currents inside the canyon are strongly influenced by the topography of the canyon walls, with a highly variable flow in the smooth wall at the east and a unidirectional offshore flow over the western wall forced by its shallow and sharp topography (Zuñiga et al., 2009).

\subsection{Sampling of sinking particles}

Two mooring lines were deployed for one year (November 2008-November 2009) at two stations located at $1200 \mathrm{~m}$ depth, one inside the canyon and one in the adjacent open slope (Fig. 1). Each line was equipped with sediment trapcurrent meter pairs, positioned at $25 \mathrm{~m}$ above the sea bottom. Sediment traps (Technicap PPS3) were equipped with 12 receiving cups with a cylindrical-conical shape with a height/diameter ratio of 2.5 and a collecting area of $0.125 \mathrm{~m}^{2}$. The traps were programmed with an interval of 7 to 8 days, which resulted in 48 sequential samples per station till the end of the monitoring period. Prior to the deployment, in the laboratory, the rotator collector was cleaned with detergent and rinsed several times with distilled water. Receiving cups were filled with a sodium borate buffered $5 \%$ formaldehyde solution in $0.45 \mu \mathrm{m}$ pre-filtered sea water to avoid degradation of the collected particles. 


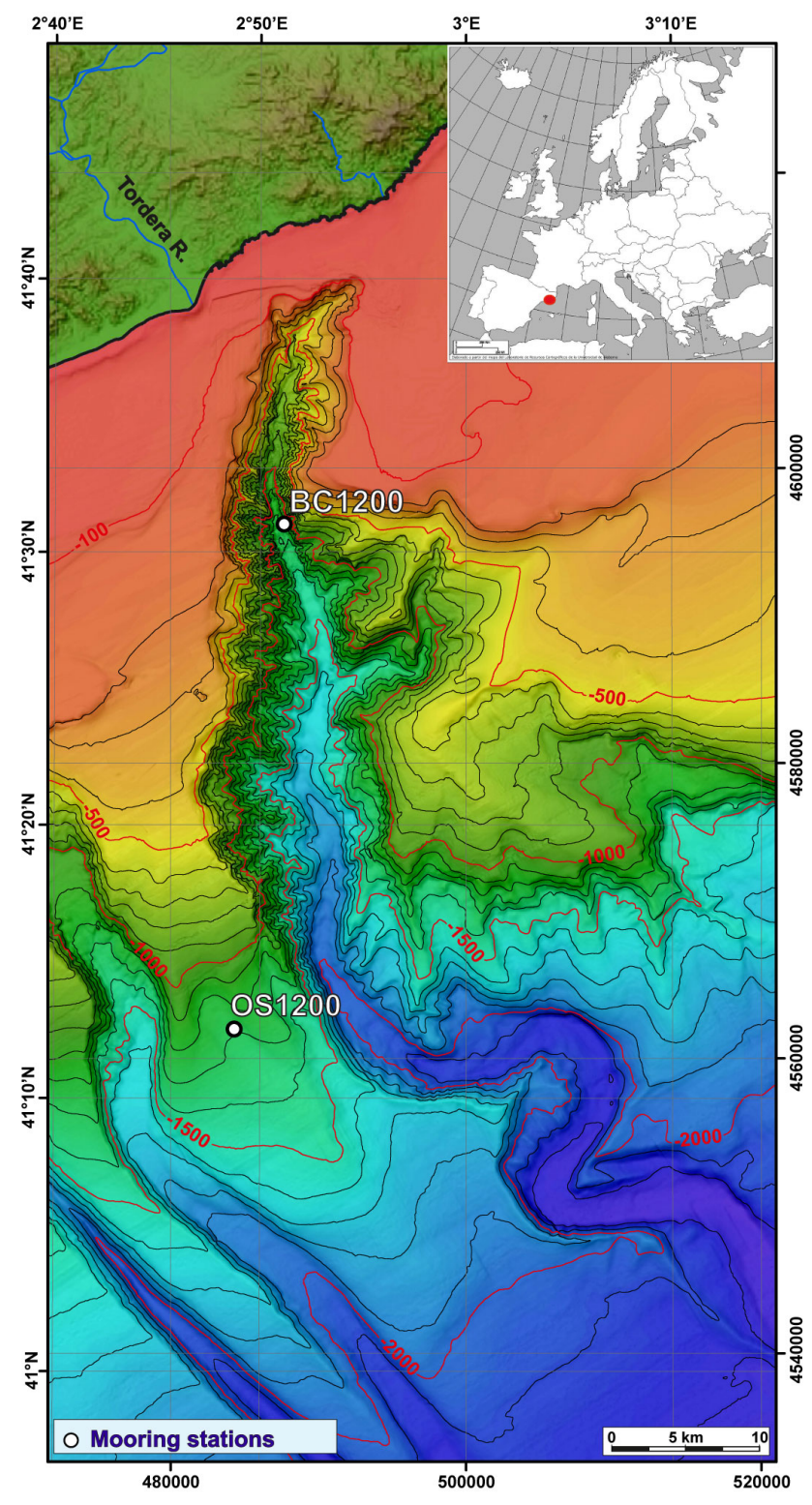

Fig. 1. Bathymetric map of Blanes canyon showing the location of the mooring station in Blanes canyon axis (BC1200) and in the adjacent southern open slope (OS1200). The location of Tordera River and the meteorological buoy is also shown. Depth in meters.

In long-term sediment traps, the use of preservative in the collecting cups is required to minimize microbial influence (Gardner et al., 1983). This may cause some analytical problems with the determination of some classes of organic compounds, but previous works demonstrated that the use of formaldehyde as preservative does not affect the determination of protein, carbohydrate and lipid contents when compared to untreated samples (Wakehamet al., 1993; Dell'Anno et al., 2002). The only possible problem is the lethal effect of the preservative on zooplankton that can lead to collections which do not represent vertical fluxes. For this reason larger swimmers (including all organisms that do not fall gravitationally through the water column but actively enter the traps) were removed before the analyses (Owens et al., 2013). After collection, samples were stored in the dark at $2-4{ }^{\circ} \mathrm{C}$ until they were processed in the laboratory.

Once in the laboratory, the samples were visually checked and the supernatant removed. Swimmers were removed by wet sieving (using sea water) on a $1 \mathrm{~mm}$ nylon mesh and hand-picking under a dissecting microscope. A high precision peristaltic pump was then used to obtain subsamples through repeated splitting of the rinsed raw samples. After that, formaldehyde and salt in excess were removed using centrifugation with cold Milli-Q water to avoid organic matter explosion, and were then freeze-dried and stored at $4{ }^{\circ} \mathrm{C}$ in the dark until further analysis. After ground to a fine powder, samples were weighed and the total mass flux (TMF) calculated using the dry weight, the trap collecting area and the sampling interval. TMF were normalized to $\mathrm{mg} \mathrm{m}^{-2} \mathrm{~d}^{-1}$.

\subsection{Biochemical composition and bioavailability of POM}

Organic carbon (OC) concentrations in the sinking particles were measured using an elemental analyzer (EA Flash series 1112 and NA2100). Organic carbon (OC) was obtained by acid digestion with $\mathrm{HCl} 6 \mathrm{M}$ of the total carbon.

Biogenic silica (opal) was analyzed using two segmented step extractions with $0.5 \mathrm{M} \mathrm{Na}_{2} \mathrm{CO}_{3}$, according to Fabres et al. (2000). Si and Al were measured using an Inductively Couple Plasma Atomic Emission Spectrometer (ICP-AES).

Chlorophyll $a$ and phaeopigment analyses were carried out according to Lorenzen and Jeffrey (1980). Pigments were extracted $\left(12 \mathrm{~h}\right.$ at $4{ }^{\circ} \mathrm{C}$ in the dark) from triplicate subaliquots of the trap material (about $10 \mathrm{mg}$ of freeze-dried material) and the sediment (10-20 mg lyophilized sediment), using $3-5 \mathrm{~mL}$ of $90 \%$ acetone as extractant. Extracts were analyzed fluorometrically to estimate chlorophyll-a, and, after acidification with $200 \mu \mathrm{L} 0.1 \mathrm{~N} \mathrm{HCl}$, to estimate phaeopigments. Different methods for assessing chlorophyll $a$ concentrations in marine particles can provide different under- or overestimates (Pinckney et al., 1994), largely because of the relative importance of the chlorophylls' degradation products, which are particularly abundant in deep-sea sediments or particles sunk into traps (Szymczakzya and Kowalewska, 2007). For this reason, chlorophyll $a$ and phaeopigment concentrations were summed up and reported as total phytopigment concentrations (Pusceddu et al., 2009). These were then converted into $\mathrm{C}$ equivalents using a conversion factor of $40 \mu \mathrm{g} \mathrm{C} \mu \mathrm{g}$ chlorophyll $a^{-1}$ (Witbaard et al., 2000; Van Oevelen et al., 2011). Protein, carbohydrate and lipid particle contents were analyzed spectrophotometrically as described in Danovaro (2010) according to Rice (1982), Gerchacov and Hatcher (1972) and Marsh and Weinstein (1966), respectively, and concentrations expressed as bovine serum albumin (BSA), glucose and tripalmitin equivalents, respectively. 
The fractions of protein and carbohydrate enzymatically digestible were assessed as described in Danovaro (2010) according to Dell'Anno et al. (2000) and reported as BSA and glucose equivalents, respectively.

Total carbohydrate, protein and lipid contents were converted into carbon equivalents $\left(\mathrm{mg} \mathrm{C} \mathrm{mg}^{-1}\right)$ using the conversion factors of $0.40,0.49$ and 0.75 , respectively, and their sum defined as the biopolymeric organic carbon (BPC) (Fabiano et al., 1995). Bioavailable organic carbon (BAOC) concentration was calculated as the sum of digestible proteins and carbohydrates converted into carbon equivalents by using the same factors as for their total pools (Danovaro et al. 2001; Pusceddu et al., 2003). The algal contribution to BPC was calculated as the percentage of total phytopigments, once converted into C equivalents, to BPC concentrations.

According to Pusceddu et al. (2010a), we used the algal contribution to BPC as a gross descriptor of freshness of organic particles (Pusceddu et al., 2000, 2009, 2010). The percentage fraction of BAOC over BPC was used as a descriptor of OM food availability for consumers (Pusceddu et al., 2003; Danovaro et al., 2001).

\subsection{Statistical analyses}

To test for temporal variations in the rates of fluxes, biochemical composition and bioavailability of sinking particulate organic matter in the Blanes canyon and the adjacent open slope, we used 2-way permutational analyses of variance (PERMANOVA; Anderson, 2001; McArdle and Anderson, 2001). The design included two orthogonal factors: seabed morphology (2 fixed levels: canyon vs. slope) and sampling time (44 fixed levels, each corresponding to about one week of particle collection by the trap). The analyses were carried out for each variable separately under unrestricted permutation of raw data (999 permutations), after calculation of Euclidean distances of normalized data. When significant differences were observed, pairwise comparison tests were carried out to assess the direction of differences between the two morphologies at each sampling time/period and among sampling periods/times, separately for each seabed morphology. The same designs and tests were used to assess temporal variations in the composition of sinking organic matter across the canyon and the adjacent open slope. The analysis was conducted including phytopigment, total and hydrolysable protein, total and hydrolysable carbohydrate and total lipid contents and using 999 permutation of residuals under the reduced model. Further, to visualize patterns of variability in the biochemical composition of sinking material, bi-plot representations after a canonical analysis of principal coordinates (CAP) were also produced. All statistical tests (PERMANOVA and the associated pairwise comparisons, CAP and the bi-plots) were carried out using the PRIMER6+ software, using the PERMANOVA and CAP routines.

\section{Results}

\subsection{Environmental conditions}

Details on atmospheric assets during the study period are described elsewhere (Lopez-Fernandez et al., 2013). Indeed several sequential storms affected the study area in autumn 2008-winter 2009 with the major storm being recorded at the end of December 2008 (Sanchez-Vidal et al., 2012). The storms, with increased wave height and Tordera river discharge, triggered increased current speeds along the Blanes canyon (Sanchez-Vidal et al., 2012; Lopez-Fernandez et al., 2013). In addition between March and May 2009 the current meter, deployed in the open slope, recorded the intrusion of Western Mediterranean Deep Waters (WMDW) (data not shown). This water intrusion was originated in the Gulf of Lions and travelled on the slope, following the stream to the north. Such plume was not recorded by the mooring deployed in the canyon.

Overall, inside the Blanes canyon, near-bottom currents were generally strongly constrained by its topography, oriented along the canyon axis in both the up and down directions. Slope currents, in contrast, did not show specific trends (Lopez-Fernandez et al., 2013). Maximum current speed was registered at the canyon mooring (up to $45.5 \mathrm{~cm} \mathrm{~s}^{-1}$ in January 2009). The maximum current speed on the slope $\left(26.4 \mathrm{~cm} \mathrm{~s}^{-1}\right)$ was observed in March 2009 (Fig. 2a-b).

\subsection{Total mass, OC and opal flux}

Total mass flux, OC and opal percentage contributions to TMF in Blanes canyon and the adjacent open slope are summarized in Table 1 and have been previously discussed by Lopez-Fernandez et al. (2013), which focuses on the physical drivers of total mass and major component fluxes (organic matter, carbonate, biogenic silica and aluminosilicates contents). Throughout the present paper, the total mass flux (TMF) and its elemental composition are provided as a general framework for better interpreting biopolymeric and bioavailable OC fluxes. TMF and the OC and opal percentage contributions to TMF yielded highly contrasting values amongst the canyon and open slope. The mean mass flux in the canyon was consistently up to one order of magnitude higher than that in the adjacent open slope (Fig. 3). Despite the differences in the mass flux mean values and in variation ranges, the two stations show similar variation coefficients (0.8 and 0.9 , respectively) (Table 1$)$.

In the open slope TMF shows three maximum peaks in mid-December 2008, mid-January and March 2009 (5.4, 7.4 and $7.1 \mathrm{~g} \mathrm{~m}^{-2} \mathrm{~d}^{-1}$, respectively) and three minimum values in November 2008, January and at the end of June 2009 (1.4, 1.5 and $0.3 \mathrm{~g} \mathrm{~m}^{-2} \mathrm{~d}^{-1}$, respectively; Fig. 3).

In the Blanes canyon, the fluxes increased substantially during winter. TMF shows four maximum peaks in December 2008, March, June and October 2009 (101.1, 55.2, 29.8 

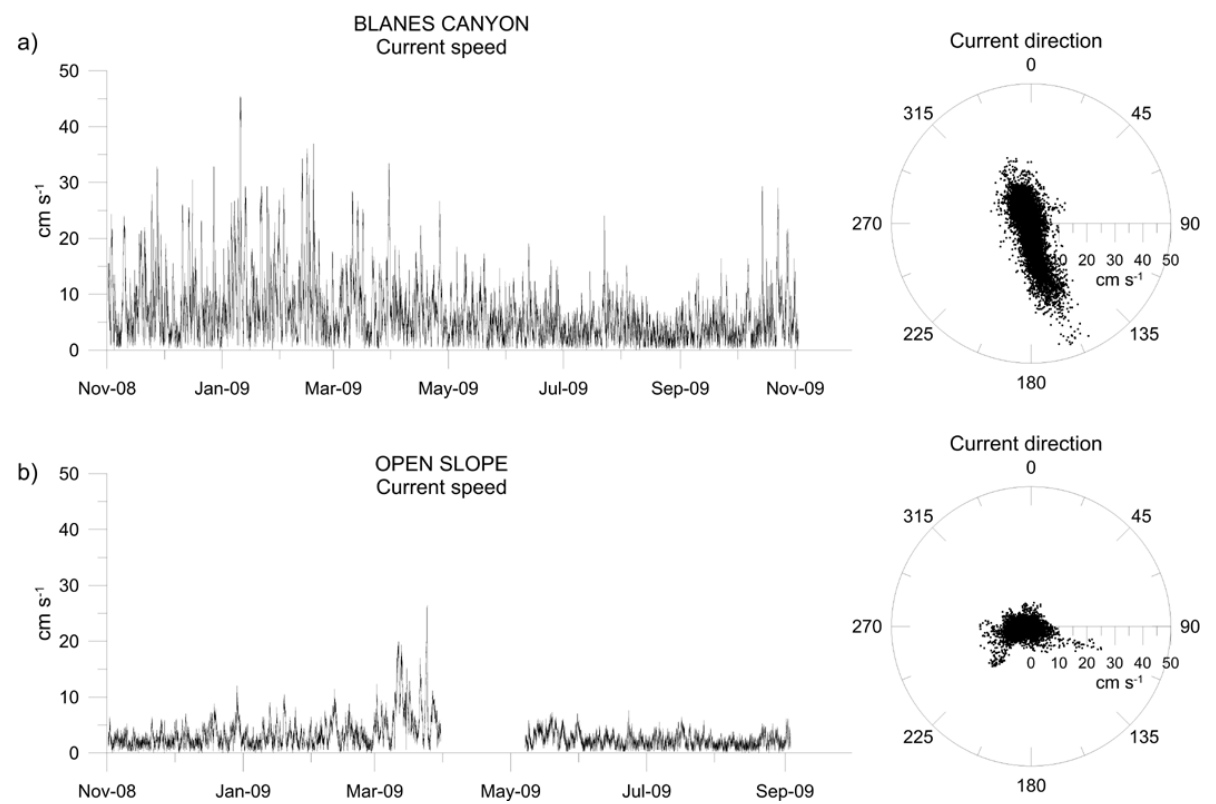

Fig. 2. Current speed and direction plots at $21 \mathrm{mab}$ in Blanes canyon (a) station and open slope (b). Radial axes in current direction polar plots are equivalent to the $y$-axis of current speed plots $\left(\mathrm{cm} \mathrm{s}^{-1}\right)$.

Table 1. Statistical parameters of total mass flux and biochemical composition of fluxes (Phytopigment, protein, carbohydrate, lipid, labile protein and carbohydrate, biopolymeric and bioavailable carbon contents) from sediment traps located in the Blanes canyon and the adjacent open slope. S.D. refers to standard deviation. C.V. refers to coefficient of variation.

\begin{tabular}{|c|c|c|c|c|c|c|c|c|c|c|c|c|}
\hline Station & & $\begin{array}{c}\text { Mass } \\
\text { flux } \\
{\left[\mathrm{g} \mathrm{m}^{-2} \mathrm{~d}^{-1}\right]}\end{array}$ & $\begin{array}{c}\% \mathrm{OC} \\
{[\%]}\end{array}$ & $\begin{array}{c}\% \text { Opal } \\
{[\%]}\end{array}$ & $\begin{array}{c}\mathrm{CPE} \\
{\left[\mu \mathrm{gg}^{-1}\right]}\end{array}$ & $\begin{array}{c}\text { Total } \\
\text { protein } \\
{\left[\mathrm{mg} \mathrm{g}^{-1}\right]}\end{array}$ & $\begin{array}{c}\text { Labile } \\
\text { protein } \\
{[\%]}\end{array}$ & $\begin{array}{c}\text { Total } \\
\text { carbohydrate } \\
{\left[\mathrm{mg} \mathrm{g}^{-1}\right]}\end{array}$ & $\begin{array}{c}\text { Labile } \\
\text { carbohydrate } \\
{[\%]}\end{array}$ & $\begin{array}{c}\text { Total } \\
\text { lipid } \\
{\left[\mathrm{mg} \mathrm{g}^{-1}\right]}\end{array}$ & $\begin{array}{c}\text { Biopolymeric } \\
\mathrm{C} \\
{\left[\mathrm{mg} \mathrm{Cg}^{-1}\right]}\end{array}$ & $\begin{array}{c}\text { Bioavailable } \\
\text { C } \\
{[\%]}\end{array}$ \\
\hline \multirow{7}{*}{$\begin{array}{l}\text { Blanes } \\
\text { canyon }\end{array}$} & Average & 22.90 & 1.1 & 1.1 & 49.27 & 2.43 & 17.1 & 2.85 & 55.1 & 1.62 & 3.55 & 23.5 \\
\hline & $\operatorname{Max}$ & 101.09 & 1.4 & 4.9 & 157.09 & 4.93 & 48.0 & 5.10 & 100.0 & 3.45 & 6.91 & 43.2 \\
\hline & Min & 0.05 & 0.7 & 0.0 & 18.29 & 0.66 & 1.2 & 1.04 & 6.9 & 1.02 & 1.75 & 11.6 \\
\hline & S.D. & 18.34 & 0.1 & 1.3 & 31.52 & 1.04 & 13.0 & 0.89 & 24.2 & 0.49 & 0.96 & 6.9 \\
\hline & C.V. & 0.80 & 0.09 & 1.18 & 0.63 & 0.42 & 0.76 & 0.31 & 0.43 & 0.30 & 0.27 & 0.29 \\
\hline & Total & 1099.11 & 1.0 & 1.0 & 2217.24 & 116.56 & 17.1 & 136.90 & 55.1 & 78.00 & 170.37 & 23.5 \\
\hline & $N$ & 44 & 44 & 44 & 44 & 44 & 44 & 44 & 44 & 44 & 44 & 44 \\
\hline \multirow{7}{*}{$\begin{array}{l}\text { Open } \\
\text { slope }\end{array}$} & Average & 2.10 & 1.6 & 2.0 & 140.56 & 2.50 & 11.9 & 7.20 & 23.8 & 2.77 & 6.18 & 13.5 \\
\hline & Max & 7.36 & 3.5 & 7.2 & 572.97 & 7.09 & 54.5 & 23.69 & 64.6 & 7.58 & 16.46 & 50.5 \\
\hline & Min & 0.00 & 1.1 & 0.1 & 1.17 & 0.02 & 0.5 & 0.29 & 1.4 & 0.01 & 0.20 & 6.5 \\
\hline & S.D. & 1.94 & 0.5 & 1.4 & 138.64 & 1.78 & 11.3 & 4.52 & 12.7 & 1.62 & 3.35 & 9.4 \\
\hline & C.V. & 0.88 & 0.30 & 0.71 & 0.98 & 0.71 & 0.94 & 0.62 & 0.53 & 0.58 & 0.54 & \\
\hline & Total & 98.85 & 1.6 & 2.0 & 6606.14 & 117.32 & 11.9 & 338.26 & 23.8 & 130.08 & 290.35 & 13.5 \\
\hline & $N$ & 44 & 44 & 44 & 44 & 44 & 44 & 44 & 44 & 44 & 44 & 44 \\
\hline
\end{tabular}

and $23.3 \mathrm{~g} \mathrm{~m}^{-2} \mathrm{~d}^{-1}$, respectively) and three minimum peaks in February, mid-May and September 2009 (0.1, 8.8 and $7.5 \mathrm{~g} \mathrm{~m}^{-2} \mathrm{~d}^{-1}$, respectively) (Fig. 3).

OC contribution to TMF in the open slope was consistently higher than in the canyon, with four relevant peaks in November 2008, and January, April and August 2009 (2.2, 2.3, 2.4 and $3.5 \%$, respectively). OC contribution to TMF in the canyon was relatively stable throughout the study period (range $0.7-1.4 \%$ ) with two apparent peaks at the end of March and end of April (1.4\% and $1.3 \%$, respectively) (Fig. 3).
Opal contribution to TMF in the open slope co-varied with the OC contents, showing four relevant peaks in November $2008(2.5 \%)$, January (3.7\%), April (7.2\%) and August $(5.7 \%)$ 2009. In the Blanes canyon the opal content of TMF showed three relevant peaks in November 2008 (3.0\%), January $(4.7 \%)$ and October (4.9\%) 2009 (Fig. 3).

\subsection{Biochemical composition and bioavailability of $\mathrm{OM}$}

Phytopigment, protein, carbohydrate, lipid, BPC and BAOC contents of sinking particles in the study area are reported in Table 1. The 2-way univariate ANOVAs revealed that the 
OPEN SLOPE

Total Mass Flux

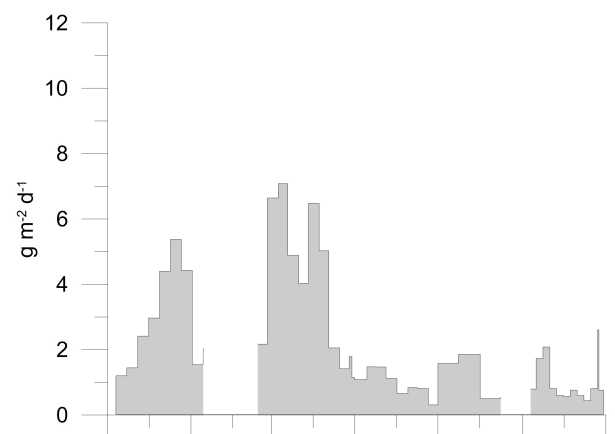

Nov-08 Jan-09 Mar-09 May-09 Jul-09 Sep-09 Nov-09
BLANES CANYON

Total Mass Flux

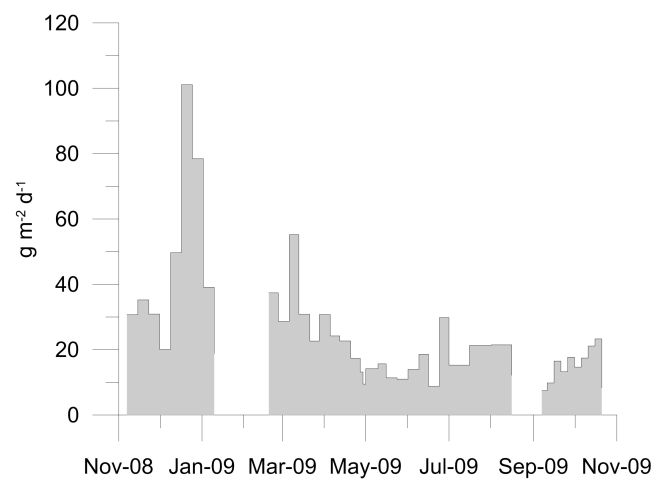

Organic Carbon

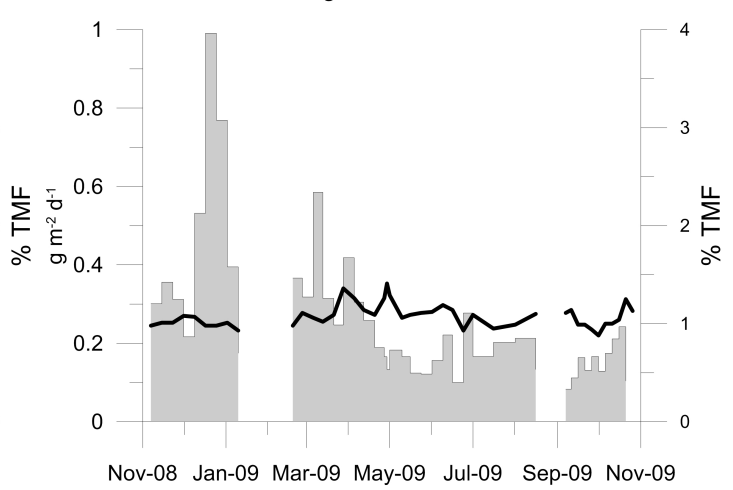

Opal

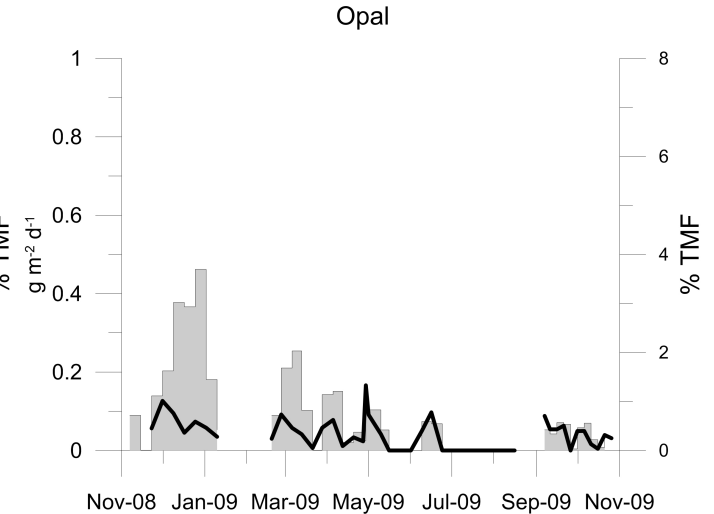

Fig. 3. Time series of total mass, organic carbon and opal fluxes $\left(\mathrm{mg} \mathrm{m}^{-2} \mathrm{~d}^{-1}\right)$ and relative organic carbon and opal contribution (black line represents the $\%$ of the compound to TMF) from the sediment traps in the Blanes canyon and the adjacent open slope at $1200 \mathrm{~m}$ depth.

contents of all investigated variables in sinking particulate material were significantly affected by the interaction between the two tested factors (time $\times$ spatial) (Table 2).

\subsection{Open slope}

In the open slope, the contents of almost all organic compounds show wide and significant temporal variations, characterized by an increase from March to April 2009, a de- crease from May to July 2009, and a maximum peak in $\mathrm{Au}-$ gust 2009 (Fig. 4a). Only total phytopigment and protein contents peaked early (in February 2009 and May 2009, respectively). Total carbohydrate concentrations ranged from 3.8 to $23.7 \mathrm{mg} \mathrm{g}^{-1}$ and displayed significant temporal variations with significant peaks in April $2009\left(11.7 \mathrm{mg} \mathrm{g}^{-1}\right)$ and August 2009 (23.7 $\left.\mathrm{mg} \mathrm{g}^{-1}\right)$. Overall, the digestible fraction of carbohydrates was about $24 \%$ of the total carbohydrate pool, with a peak (65\%) in February 2009 (corresponding 
Table 2. Results of univariate and multivariate analyses of variance testing for habitat and temporal variability in fluxes and biochemical composition of fluxes in the Blanes canyon and the adjacent open slope. ${ }^{* * *}=P<0.001$; ns $=$ not significant. df refers to degrees of freedom.

\begin{tabular}{|c|c|c|c|c|c|}
\hline Variable & Contrast & $\mathrm{df}$ & MS & $F$ & $P$ \\
\hline \multirow[t]{4}{*}{ Phytopigment } & Canyon vs. Slope $(M)$ & 1 & 54.298 & 34.17 & $* * *$ \\
\hline & Sampling Time $(T)$ & 43 & 3.253 & 1151.90 & $* * *$ \\
\hline & $M \times T$ & 43 & 1.589 & 562.63 & $* * *$ \\
\hline & Residuals & 176 & 0.003 & & \\
\hline \multirow[t]{4}{*}{ Algal fraction of BPC } & Canyon vs. Slope $(M)$ & 1 & 32.796 & 32.23 & $* * *$ \\
\hline & Sampling Time $(T)$ & 43 & 4.254 & 213.11 & $* * *$ \\
\hline & $M \times T$ & 43 & 1.018 & 50.97 & $* * *$ \\
\hline & Residuals & 176 & 0.020 & & \\
\hline \multirow[t]{4}{*}{ Total protein } & Canyon vs. Slope $(M)$ & 1 & 0.775 & 0.23 & $\mathrm{~ns}$ \\
\hline & Sampling Time $(T)$ & 43 & 2.239 & 20.11 & *** \\
\hline & $M \times T$ & 43 & 3.403 & 30.56 & $* * *$ \\
\hline & Residuals & 176 & 0.111 & & \\
\hline \multirow[t]{4}{*}{ Labile protein } & Canyon vs. Slope $(M)$ & 1 & 5.560 & 1.73 & $\mathrm{~ns}$ \\
\hline & Sampling Time $(T)$ & 43 & 2.567 & 49.19 & $* * *$ \\
\hline & $M \times T$ & 43 & 3.207 & 61.44 & $* * *$ \\
\hline & Residuals & 176 & 0.052 & & \\
\hline \multirow[t]{4}{*}{ Labile protein fraction } & Canyon vs. Slope $(M)$ & 1 & 2.487 & 0.70 & ns \\
\hline & Sampling Time $(T)$ & 43 & 2.372 & 74.95 & $* * *$ \\
\hline & $M \times T$ & 43 & 3.557 & 112.41 & $* * *$ \\
\hline & Residuals & 176 & 0.032 & & \\
\hline \multirow[t]{4}{*}{ Total carbohydrate } & Canyon vs. Slope $(M)$ & 1 & 117.630 & 62.19 & $* * *$ \\
\hline & Sampling Time $(T)$ & 43 & 1.421 & 85.57 & $* * *$ \\
\hline & $M \times T$ & 43 & 1.892 & 113.88 & $* * *$ \\
\hline & Residuals & 176 & 0.017 & & \\
\hline \multirow[t]{4}{*}{ Labile carbohydrate } & Canyon vs. Slope $(M)$ & 1 & 8.289 & 2.70 & ns \\
\hline & Sampling Time $(T)$ & 43 & 2.335 & 18.25 & $* * *$ \\
\hline & $M \times T$ & 43 & 3.065 & 23.96 & $* * *$ \\
\hline & Residuals & 176 & 0.128 & & \\
\hline \multirow{4}{*}{$\begin{array}{l}\text { Labile carbohydrate } \\
\text { fraction }\end{array}$} & Canyon vs. Slope $(M)$ & 1 & 104.580 & 49.01 & $* * *$ \\
\hline & Sampling Time $(T)$ & 43 & 1.381 & 33.40 & $* * *$ \\
\hline & $M \times T$ & 43 & 2.134 & 51.60 & $* * *$ \\
\hline & Residuals & 176 & 0.041 & & \\
\hline \multirow[t]{4}{*}{ Total lipid } & Canyon vs. Slope $(M)$ & 1 & 85.979 & 49.41 & $* * *$ \\
\hline & Sampling Time $(T)$ & 43 & 2.190 & 47.95 & $* * *$ \\
\hline & $M \times T$ & 43 & 1.740 & 38.11 & $* * *$ \\
\hline & Residuals & 176 & 0.046 & & \\
\hline \multirow[t]{4}{*}{ Biopolymeric C } & Canyon vs. Slope $(M)$ & 1 & 70.291 & 35.58 & $* * *$ \\
\hline & Sampling Time $(T)$ & 43 & 2.223 & 32.18 & $* * *$ \\
\hline & $M \times T$ & 43 & 1.976 & 28.60 & $* * *$ \\
\hline & Residuals & 176 & 0.069 & & \\
\hline \multirow[t]{4}{*}{ Bioavailable C } & Canyon vs. Slope $(M)$ & 1 & 1.405 & 0.42 & $\mathrm{~ns}$ \\
\hline & Sampling Time $(T)$ & 43 & 2.053 & 13.03 & $* * *$ \\
\hline & $M \times T$ & 43 & 3.386 & 21.49 & $* * *$ \\
\hline & Residuals & 176 & 0.158 & & \\
\hline \multirow{4}{*}{$\begin{array}{l}\text { Bioavailable fraction } \\
\text { of BPC }\end{array}$} & Canyon vs. Slope $(M)$ & 1 & 102.520 & 57.99 & $* * *$ \\
\hline & Sampling Time $(T)$ & 43 & 1.720 & 28.85 & $* * *$ \\
\hline & $M \times T$ & 43 & 1.768 & 29.65 & $* * *$ \\
\hline & Residuals & 176 & 0.060 & & \\
\hline \multirow{4}{*}{$\begin{array}{l}\text { Biochemical } \\
\text { composition }\end{array}$} & Canyon vs. Slope $(M)$ & 1 & 515.170 & 55.70 & $* * *$ \\
\hline & Sampling Time $(T)$ & 43 & 14.716 & 80.18 & $* * *$ \\
\hline & $M \times T$ & 43 & 9.249 & 50.39 & $* * *$ \\
\hline & Residuals & 176 & 0.184 & & \\
\hline
\end{tabular}



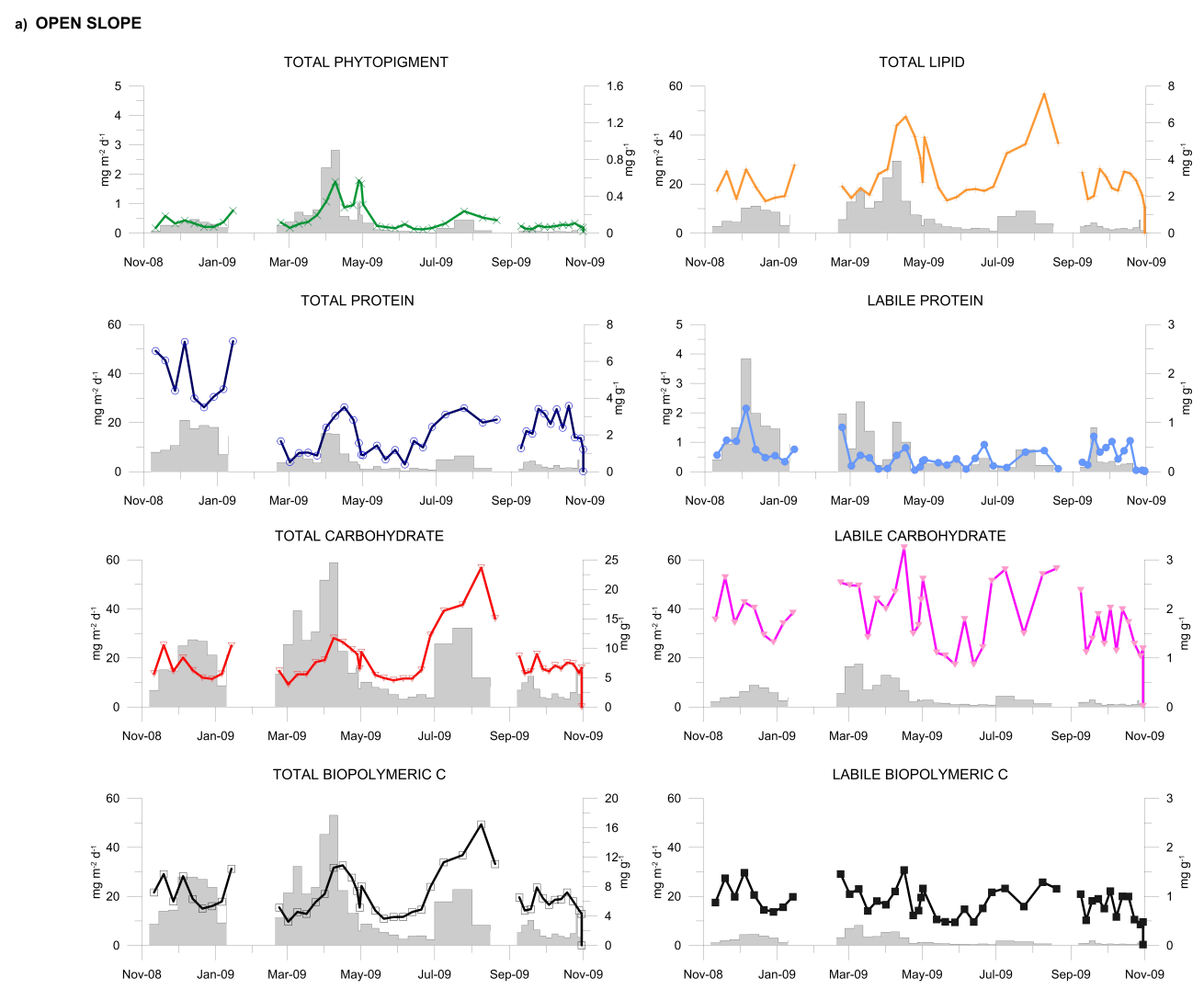

b) BLANES CANYON
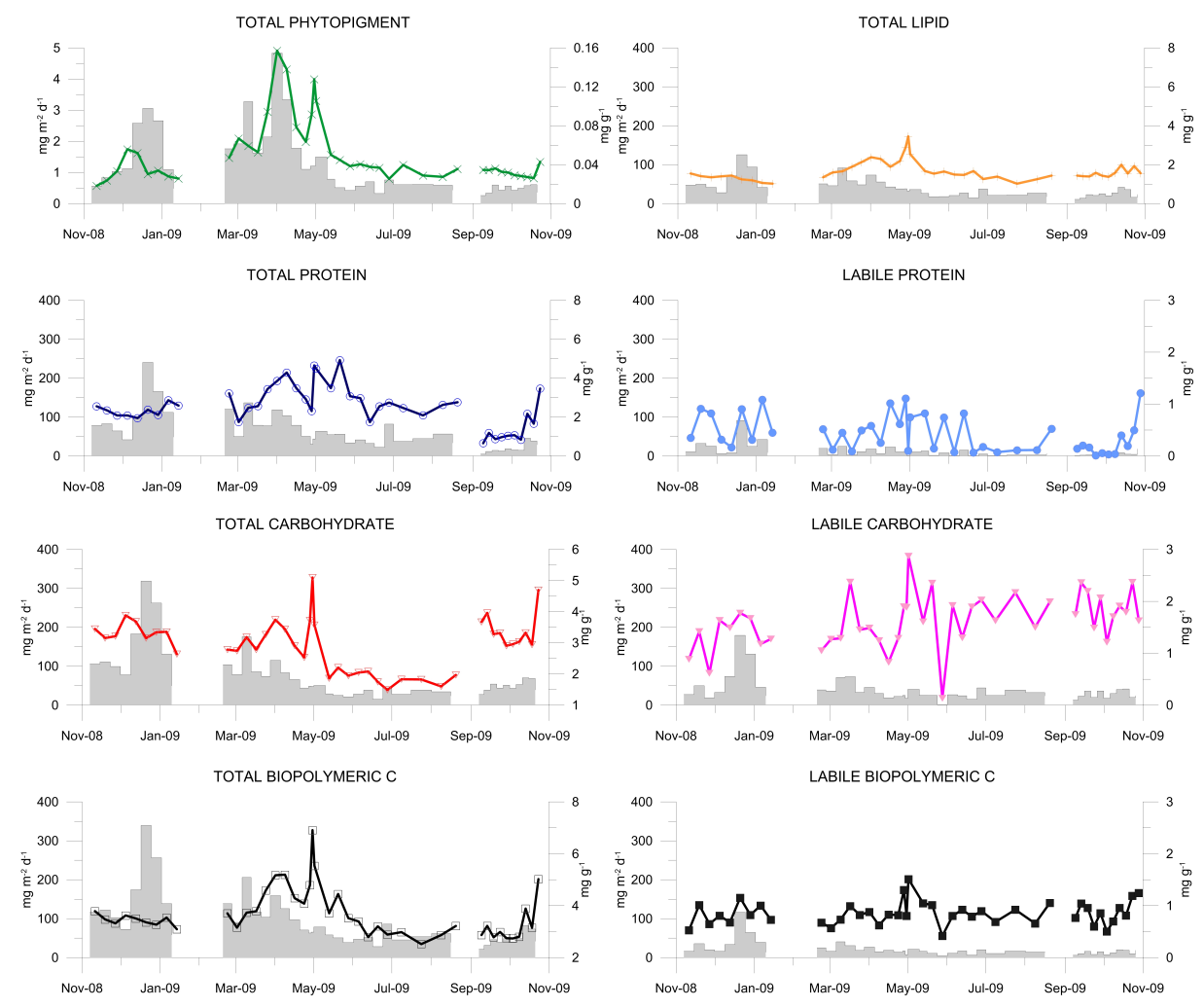

Fig. 4. Time series of organic compounds fluxes $\left(\mathrm{mg} \mathrm{m}^{-2} \mathrm{~d}^{-1}\right)$ and organic compounds contents in the open slope (a) and in the Blanes canyon (b) (line represents the $\mathrm{mg}^{-1}$ ) from the sediment traps at $1200 \mathrm{~m}$ depth. 
to $2.5 \mathrm{mg}$ labile carbohydrates $\mathrm{g}^{-1}$ ). Total protein concentrations ranged from 0.02 to $7.1 \mathrm{mg} \mathrm{g}^{-1}$, and displayed three significant peaks at the end of January $\left(7.09 \mathrm{mg} \mathrm{g}^{-1}\right)$, in April $\left(3.5 \mathrm{mg} \mathrm{g}^{-1}\right)$ and at the end of July $2009\left(3.5 \mathrm{mg} \mathrm{g}^{-1}\right)$. Labile proteins represent on average about $12 \%$ of the total protein pool, with a maximum value of $54 \%$ (corresponding to a concentration of $0.9 \mathrm{mg} \mathrm{g}^{-1}$ ) in December 2008. Total lipid concentrations follow the same temporal pattern as the one observed for total carbohydrates, ranged from 1.4 to $7.6 \mathrm{mg} \mathrm{g}^{-1}$ with significant peaks in April 2009 $\left(6.3 \mathrm{mg} \mathrm{g}^{-1}\right)$, and August $2009\left(7.6 \mathrm{mg} \mathrm{g}^{-1}\right)$. Overall, total particulate carbohydrates were the dominant class of organic compounds with an average contribution to the BPC around $46 \%$, followed by lipids (33\%) and proteins (21\%). BPC represents about $35 \%$ of the total OC flux in the open slope (range $1-51 \%$ with a $36 \%$ of variation on an annual basis). A minor fraction (on average $16 \%$, range 6$50 \%$ ) of BPC reaching the sea bottom in the slope was enzymatically digestible. Total phytopigment concentrations explained only $23 \%$ of BPC variance (Type-I regression, $n=144, p<0.05$ ), with the remaining $67 \%$ of BPC reaching the open slope sediments being associated with non-algal sources. BPC and BAOC covary significantly in the open slope, with about $72 \%$ of BPC variance being explained by variations in BAOC contents (Type-I regression, $n=144$, $p<0.001)$.

\subsection{Canyon}

In the canyon, the contents of almost all organic compounds show wide and significant temporal variations, most of them were characterized by an increase from March to May 2009, with a maximum peak in May 2009, and a decrease from June 2009 (Fig. 4b). Total carbohydrate contents ranged from 1.5 to $5.1 \mathrm{mg} \mathrm{g}^{-1}$ and peaked in May 2009 $\left(5.1 \mathrm{mg} \mathrm{g}^{-1}\right)$, when the highest peak in labile carbohydrate content $\left(2.9 \mathrm{mg} \mathrm{g}^{-1}\right)$ was also observed. Overall, enzymatically digestible carbohydrates in the fluxes of the Blanes canyon were about $58 \%$ of the total carbohydrate pool. Total protein concentrations do not display any significant peak, though generally higher protein contents were observed in April-May 2009 and ranged from 0.6 to $4.9 \mathrm{mg} \mathrm{g}^{-1}$. Overall, labile protein represented on average about $17 \%$ of the total protein pool, with a relative peak in April 2009 (48\%), corresponding to $1.1 \mathrm{mg}$ of labile protein $\mathrm{g}^{-1}$. Total lipid ranged from 1.0 to $3.5 \mathrm{mg} \mathrm{g}^{-1}$ and followed the same temporal pattern as the one observed for total carbohydrate contents with higher values in March-April 2009 (up to $3.5 \mathrm{mg} \mathrm{g}^{-1}$ ). In the Blanes canyon, protein, carbohydrate and lipid contributed, on annual average, almost equally (almost $33 \%$ each) to the BPC flux. In the canyon, BPC represents, on annual average, about $33 \%$ of the total OC flux (range $20-49 \%$, with a $17 \%$ of variation on an annual basis). About $24 \%$ (range $11-43 \%$ ) of BPC reaching the sea bottom in the canyon was enzymatically digestible. Total phytopigment concentrations explained about $64 \%$ of BPC variance (Type-I regression, $n=144, p<0.05$ ), with the remaining $36 \%$ of BPC reaching the canyon sediments being associated with non-algal sources. BPC and BAOC covary significantly also in the canyon, with about $85 \%$ of BPC variance being explained by variations in BAOC contents (Type-I regression, $n=144$, $p<0.001)$.

\subsection{Comparison between fluxes in the open slope and the canyon}

Pairwise comparison tests revealed that, for almost the entire study period, fluxes of all investigated variables and the labile fractions of protein and carbohydrate pools were significantly higher in the canyon than in the open slope (Fig. 6). The same tests carried out on OM contents (data not shown) reveal different patterns for each investigated variable with contents in the open slope higher than in the canyon being more frequently observed. The PERMANOVA tests (Table 2) revealed that the biochemical composition of sinking particulate matter varied between the canyon and the slope and, in both sites, varied significantly with sampling time. The biplot produced after the CAP analysis reveals that, during the study period, the biochemical composition of fluxes in the canyon fluctuated more widely than in the open slope. Two major clusters were identified: one in the canyon in December 2008 concurrently with the major storm and associated with increased fluxes of nutritionally important molecules (i.e., total and labile proteins and labile carbohydrates). Another cluster included samples collected in the canyon and the open slope in March 2009, concurrent with the early phases of the phytoplankton bloom and associated with increased fluxes of total phytopigments (Fig. 7).

\section{Discussion}

\subsection{Mass fluxes in the Blanes canyon and in the adjacent open slope}

While several studies on continental margins differentiated between particle fluxes inside and outside of submarine canyons (Puig and Palanques, 1998; Monaco et al., 1999; Martin et al., 2006), there have been only few studies simultaneously assessing both seasonal and spatial changes in the biochemical characteristics of settling organic matter in the canyons of the Mediterranean Sea (Tesi et al., 2008; SanchezVidal et al., 2009; Pasqual et al., 2011). Furthermore, information on the readily degradable fraction of sinking organic particles is practically nonexistent. Consequently, the present study constitutes the first report considering synoptically seasonal and spatial changes in the characteristics of the settling organic matter, including its enzymatically digestible fraction, in a Mediterranean submarine canyon and its adjacent open slope. This study is based on a biomimetic approach and in spite of its limitations this technique has provided, 

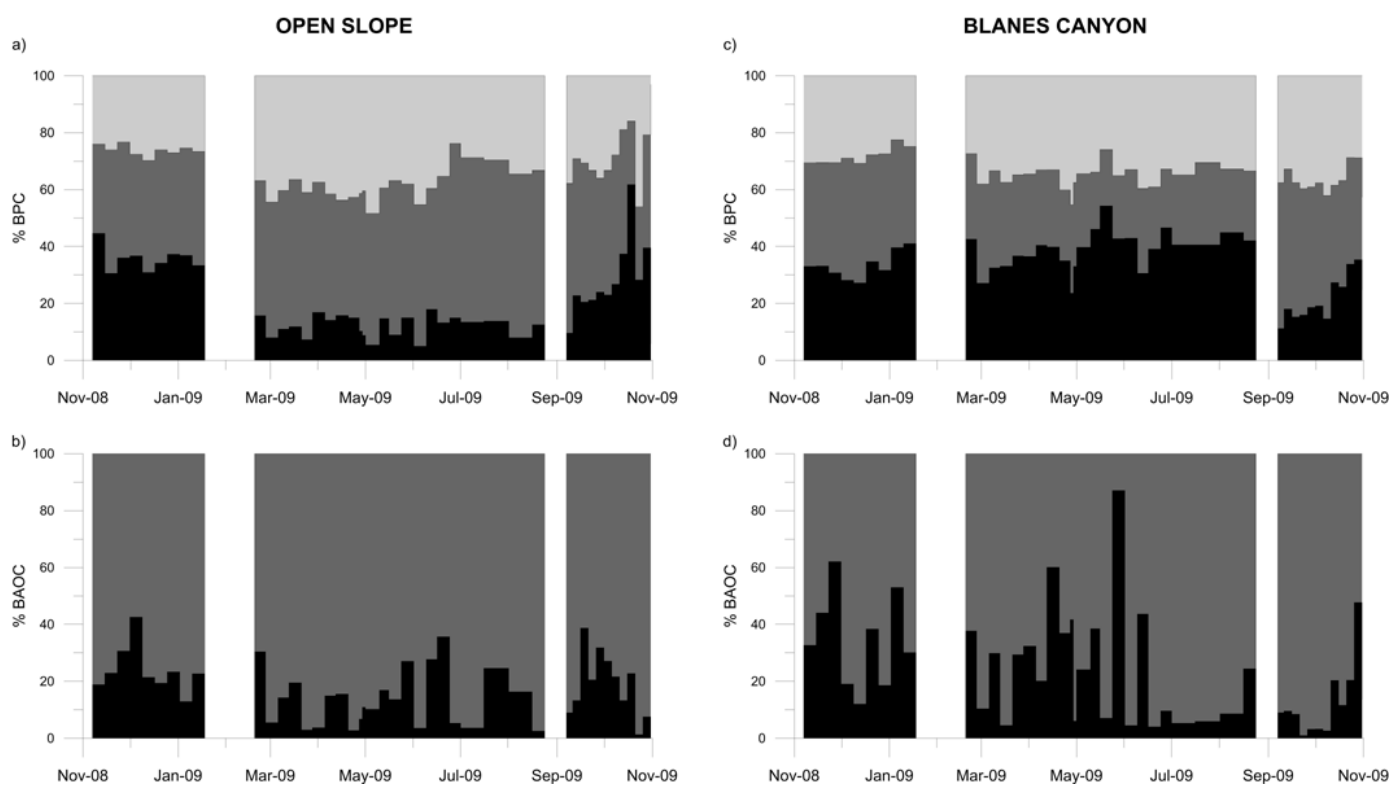

Fig. 5. Temporal changes in the biochemical composition of settling particles at 25 mab. Data are presented as percentage contributions of proteins, carbohydrates and lipids to biopolymeric C (\% BPC) and as percentage contributions of labile proteins and labile carbohydrates to bioavailable organic carbon (\% BAOC) in the two sampling stations open slope (a, b) and Blanes canyon (c, d), respectively.

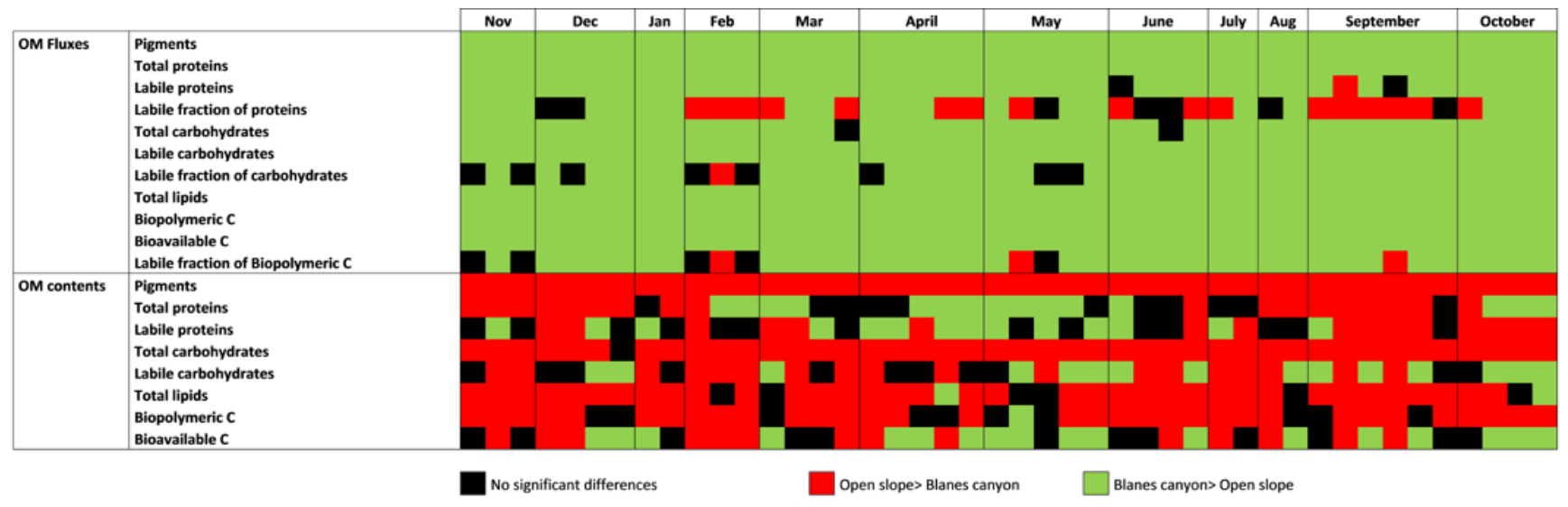

Fig. 6. Pairwise test of organic matter fluxes and contents between the two morphologies at each sampling time/period and among sampling periods/times, separately for each seabed morphology.

for heterotrophic consumers, quantitative information on the availability of food for many benthic ecosystems (Mayer et al., 1995; Grémare et al., 1997, 2002, 2003, 2005; Dauwe et al., 1999; Dell'Anno et al., 2000; Danovaro et al., 2001; Vandewiele et al., 2009; Bourgeois et al., 2011).

We report here that during the entire year of the study, the mass fluxes in the axis of the canyon were consistently one order of magnitude higher than those in the adjacent open slope at equal depth. Overall, the presence of canyons drastically alters the regional bathymetry by reducing the distance between terrestrial sediment sources and the shelf break, introducing steep slopes closer to the shoreline and intersecting the along-shelf sediment transport system (Mul- lenbach et al., 2004). Thus, submarine canyons may capture inputs delivered through the river mouths, littoral drift sediments and sediments from relict shelf bodies (Lastras et al., 2011). Such a striking difference has been already described for the Blanes canyon, where the TMF continuously increases from the head of the canyon at $300 \mathrm{~m}$ depth until $1500 \mathrm{~m}$ depth, unlike in the adjacent open slope where the TMF decrease with the distance to coast (Lopez-Fernandez et al., 2013). Clearly there is a difference between the flows in the two sampling stations due to the location and distance of the "shelf-break". The station OS 1200 situated at approximately $20 \mathrm{~km}$ to the $200 \mathrm{~m}$ isobaths, presents on average a TMF of $2380.9 \mathrm{mg} \mathrm{m}^{-2} \mathrm{~d}^{-1}$ with OC and opal fluxes 


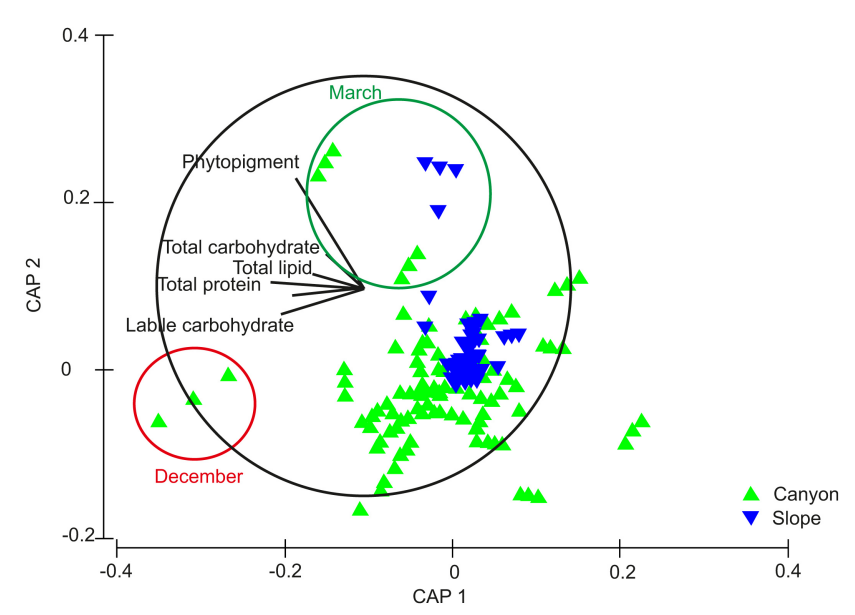

Fig. 7. Bi-plot representations after a canonical analysis of principal coordinates (CAP). Samples from the Blanes canyon and the adjacent open slope have been differentiated.

on average of 40.6 and $49.9 \mathrm{mg} \mathrm{m}^{-2} \mathrm{~d}^{-1}$, respectively (1.7 and $2.1 \%$ of the TMF, respectively). However, in the station BC1200 situated around $10 \mathrm{~km}$ to the $200 \mathrm{~m}$ isobaths, these fluxes were higher, 22 898.2, 240.6 and 269.6 for the TMF, OC and opal fluxes, respectively, and the OC and opal contribution to the TMF were lower (1.1 and $1.2 \%$, respectively). Nevertheless, it must be considered that the pathway of organic and inorganic matter is not solely driven by vertical settling from the sea surface to the deep ocean, as a large proportion of particulate matter is transported by lateral advection before deposition on the deep seafloor. Therefore, we cannot exclude that a certain fraction of the differences observed in TMF between the canyon and the open slope could be ascribed to the difference in distance from the coast of the two sampling stations, which could have led traps to intercept particles transported over different horizontal distances. In this regard, however, Lopez-Fernandez et al. (2013) showed that the Blanes canyon is mainly influenced by lateral particle inputs, with a strong homogenization process where the load of sediment has been diluted by terrigenous and resuspended material, whereas the slope is more influenced by the vertical transport, tightly connected with biological processes occurring in the upper ocean layers.

The differences in mass flux between the canyon and the adjacent open slope were accentuated during storm periods. The repeated action of high waves increased the shelf water density by resuspension and caused down-canyon currents promoting the transport of the suspended loads through Blanes submarine canyon (Palanques et al., 2006; SanchezVidal et al., 2012).

The total mass flux for all the above mentioned canyons, including Blanes, is typically dominated by a lithogenic fraction. As a result, the OC contribution to the TMF in the Blanes canyon and the adjacent open slope is very low (ranging $0.7-1.4 \%$ and $1.1-3.5 \%$, respectively), in concordance with studies carried out in other Mediterranean continental margins indented by submarine canyons (Martin et al., 2006; Pasqual et al., 2010). The large dominance of the lithogenic fraction in settling particles from both the canyon and its adjacent open slope is indicative of the presence of a conspicuous input of material entering the trap either from terrigenous inputs or sediment resuspension. This hypothesis is corroborated by the presence of relatively high concentrations of carbohydrates in the trap samples, which represented on average $0.3 \%$ and $0.7 \%$ of TMF in the canyon and open slope, respectively, and $28.7 \%$ and $44.5 \%$, respectively, of OC. Following the order of overall relative lability for biochemical classes assigned by Wakeham et al. (1997) (pigments $>$ lipids $>$ proteins $>$ carbohydrates) carbohydrates represent the most refractory fraction of organic compounds analyzed in this study.

\subsection{Bioavailability of sinking organic particles}

The biological material was present and evident in both systems during the entire study period and, in some cases, especially in the open slope, contributed significantly to the particle downward fluxes. The OC contribution to the TMF generally decreased with increasing TMF, confirming a preeminent dilution of organic inputs with terrigenous and/or resuspended material, which was even more accentuated inside the canyon. At the same time, during this study, the organic fraction of the TMF is generally higher in the open slope than in the canyon axis. This result would indicate that, despite the large input of inorganic material reaching the sediments, heterotrophic consumers in the open slope sediments may profit from a concentration of food particles consistently larger than that available in the canyon at equal depths. Nevertheless, our results also show that the slope site was mainly characterized by a remarkable seasonal variability in the food quality of sinking particles, with major peaks associated with the seasonal cycle of biological production in the euphotic zone, whereas the canyon site showed a more pronounced temporal variability in the quantity of sinking particles. This striking difference in the quantity/quality of particles sinking in the canyon axis and the adjacent open slope is likely to have conceivable consequences for the nutrition of the deepsea benthos inhabiting the two different habitats. A certain benthic organism living inside the Blanes canyon would indeed need to ingest more particles to fulfill its food requirements than another one living in the adjacent slope, where the $\mathrm{OC}$ fraction of sinking particles is consistently and almost constantly higher than in the canyon. In fact, it can be roughly calculated that an animal in the canyon exposed to a mass unit of sinking material can profit approximately $1 \% \mathrm{OC}$, which is about half the amount that an animal in the slope receives. This result indicates that deep-sea benthos in the canyon are generally exposed to a rain of preeminently inorganic material. Nevertheless, our data also indicate that the labile (enzymatically digestible) fraction of organic matter 
reaching the benthos in the canyon is generally higher than that in the open slope. Thus, the food limitation of the benthos inhabiting deep-sea sediments in the canyon, despite the dilution of OC in a preeminently inorganic matrix, is partly counterbalanced by a higher organic matter bioavailability ( $8 \%$ of OC is enzymatically digestible) than in the open slope $(5 \%)$.

According to the optimal foraging theory (Shoener, 1971; Pyke et al., 1977), our results suggest that, although a heterotrophic organism living in the canyon should spend more energy in "searching" for OC, OC, once acquired, is more labile than that more easily accessed by an animal living on the open slope. This result indicates that organisms facing particle transport from the canyon are penalized by the mostly inorganic flux, but can counterbalance this, profiting inputs of more labile organic particles.

The results of this study, therefore, provides new insights on the differential modalities that deep-sea benthos inhabiting largely different habitats (e.g., canyon vs. open slope) may experience to survive in a generally food depleted environment. Our results confirm recent studies showing that elevated organic matter inputs in canyons may favor the faunal contribution to carbon processing and create hotspots of faunal biomass and carbon processing along the continental shelf (Van Oevelen et al., 2011). However, whether these inputs have always a positive effect on deep-sea benthos depends also on the rates of sinking and the overall amount of sediment deposited on the deep-sea floor.

By rapidly conveying the organic material produced in the upper water column, submarine canyons are able to often sustain more biomass and biodiversity than the nearby open slope areas (Bianchelli et al., 2008). Moreover, differences in biodiversity between canyons and open slopes are generally larger in terms of faunal community structure (i.e., beta diversity) than in terms of species richness (Danovaro et al., 2009). These differences are mostly explained by the availability of food particles in the sediment (Danovaro et al., 2009), which in turn reflect the nature, origin and food quality of inputs from the upper water column (Danovaro et al., 1999). Thus, our results allow hypothesizing that those faunal differences between soft bottom sediments of canyons and neighboring open slopes could be also the result of community adaptations to different combinations of food quantity and quality in the two different habitats.

\subsection{Hydrodynamic and climatic controls of bioavailable organic matter inputs to deep sea ecosystems}

Whether the pattern of mass fluxes in the Blanes canyon can be extrapolated to other submarine canyons along Mediterranean margins remains an open question. In fact, several Mediterranean submarine canyons have been defined as major conduits for OC to the deep-sea basin due to local hydrodynamics conditions (Martin et al., 2006; Palanques et al., 2008; Zuñiga et al., 2009). Nevertheless, recent studies have also demonstrated that different (even adjacent) canyons may show large differences in the quantitative and qualitative characteristics of sedimentary organic matter, and that these differences are not only related to the different morphological features of different canyons, but can also depend on the timing of sampling (Pusceddu et al., 2010). In fact, canyons are often episodic event-dominated systems (Palanques et al., 2012), which means that the inputs of particles reaching the interior of canyons are largely (sometimes stochastically) influenced by local climate anomalies, involving river flood events, wind dust inputs and high energy hydrodynamic processes as sea storms, dense shelf water cascading and deep ocean convection (Canals et al., 2006; Sanchez-Vidal et al., 2012; Palanques et al., 2012), but also by primary production at the surface (Danovaro et al., 2001). In this regard, in fact, it must be considered that the sediment transport through submarine canyons is neither constant nor unidirectional, rather it has a pulse-like behavior (Palanques et al., 2012). One of the most dramatic examples of pulsed processes driving the transport of large amounts of sediment and organic matter to the deep sea occurs during severe coastal storms which can be highly efficient in transporting OC from shallow waters on the shelf down to deep waters (Sanchez-Vidal et al., 2012).

Variations in the biochemical composition of sinking particles observed in this study during the storm partially resemble the consequences of dense shelf water cascading and severe coastal storms on the availability of organic C for the deep-sea benthos (Sanchez-Vidal et al., 2012). The biochemical composition presents temporal variations during the sampling period, this highlights the different sources of the organic material arriving to $1200 \mathrm{~m}$ deep. During the autumn-winter storms period our data present an increase in total protein and labile contribution to the BPC and low values of lipids, this behavior is not observed during other seasons (Fig. 5). In spring and summer, the hydrodynamic conditions are less rough than in storm period, these two seasons are marked by an increase in lipids. Differences in biochemical composition highlight the different structure in the communities on the water column (Fig. 5). Lipids are more readily available to consumers than proteins (Taylor et al., 1986), so we could point out that a large amount of labile particles arriving during storms period, against an overwhelming quantity of sediment transported, come by sediment resuspension from the continental shelf and are redistributed towards the deep sea.

The possible advantage of a more labile food for the deepsea benthos receiving inputs forced by climate anomalies at the sea surface could be however counterbalanced and even canceled by the physical and mechanical disturbance generated by the gravity flow of inorganic particles, possibly suffocating the sea bottom (Pusceddu et al., 2010, 2013), so our results confirm that severe coastal storms can have important and almost immediate consequences on the functioning of the whole system down to the deep seafloor (Sanchez-Vidal et al., 2012). 


\subsection{Synopsis and conclusions}

In this study we show that the organic matter collected by sediment traps in spring had a higher nutritional value than in late autumn-winter, and this feature was shared by both the canyon and the adjacent open slope (Figs. 4b, 6). This difference is likely to be due to the typical spring plankton bloom described by several authors in the study area (Estrada et al., 1996; Rossi et al., 2003). During this period the biochemical composition of BPC was characterized by increasing lipid contributions compared with those observed during the storm period, characterized by higher protein contents (Fig. 5). Along with proteins, lipids can represent a preferential source of energy for benthic feeders (Medernach et al., 2001; Grémare et al., 1997). In the slope (more influenced by pelagic sedimentation), the increase in the nutritional value of sinking particles is magnified by the effect of the deepsea convection, that lead the injection of nutrients up into the surface water.

In summer, sediment trap samples showed an increase in the nutritional value of the sediment comparable to the increase during the spring bloom. Lopez-Fernandez et al. (2013) pointed out during this period an input of Saharan dust in the area. Fertilization process by wind dust and a consequent increase in the sinking flux have been previously described by several authors in the northwestern Mediterranean (Zuñiga et al., 2008; Lee et al., 2009; Pasqual et al., 2011 ). This dust brings new nutrients such as inorganic phosphorous and iron to the surface waters and could increase autotrophic production, and hence the efficiency of the biological C pump in oligotrophic oceans (Pulido-Villena et al., 2008). The entrance of nutrients is more accentuated in the open slope where the pelagic processes are more clearly recorded.

While most of variability in the rates of particle transport can be reliably explained with physical processes like hydrodynamism and climate forcing, we cannot exclude that the differences in the biochemical composition and bioavailability of sinking particles in the Blanes canyon and the adjacent open slope can be also modulated by biological constraints in the water column (e.g., through grazing). Also, we note that our inferences about the biochemical composition of particles should be considered with some caution, as it has been demonstrated elsewhere that the relative proportions of protein, carbohydrate and lipid concentrations and estimates of bioavailability can vary considerably depending on the analytical technique utilized (Hedges et al., 2001).

Nevertheless, our results, based on a biomimetic approach, confirm that in both the submarine canyon and the openslope, the bioavailable organic matter delivery towards deepsea ecosystems are strongly controlled by hydrodynamic processes (sea storms, dense-shelf water cascading and offshore convection) and annual bioclimatic controls (winter-spring primary production bloom).
Acknowledgements. We thank all people on board R/V García del Cid for their help and dedication during the PROMETEO cruises. This work has been undertaken in the framework of PROMETEO (CTM2007-66316-C02-01/MAR), DOS MARES (CTM2010-21810-C03-01), and Consolider Ingenio 2010 GRACCIE (CSD2007-00067) RTD projects funded by the Spanish Government, and HERMIONE (226354-HERMIONE) RTD project funded by the European Commission, and the excellence research groups grant 2009-SGR-1305 by the government of Catalonia and by the Flagship Project RITMARE - The Italian Research for the Sea - coordinated by the Italian National Research Council and funded by the Italian Ministry of Education, University and Research within the National Research Program 2011-2013. P. Lopez-Fernandez benefit from the Spanish FPI Grant (BES-2008-009374).

Edited by: J. Middelburg

\section{References}

Amblas, D., Canals, M., Urgeles, R., Lastras, G., Liquete, C., Hughes-Clarke, J., Casamor, J. L., and Calafat, A. M.: Morphogenetic mesoscale analysis of the northeastern Iberian margin, NW Mediterranean Basin, Mar. Geol., 234, 3-20, 2006

Anderson, M. J.: A new method for non-parametric multivariate analysis of variance, Austral. Ecol., 26, 32-46, 2001.

Bianchelli, S., Gambi, C., Pusceddu, A., and Danovaro, R.: Trophic conditions of sediments in a deep-sea canyon in the Adriatic Sea, Chem. Ecol., 24, 101-109, 2008

Bonnin, J., Heussner, S., Calafat, A., Fabres, J., Palanques, A., Durrieu de Madron, X., Canals, M., Puig, P., Avril, J., and Delsaut N.: Comparison of horizontal and downward particle fluxes across canyons of the Gulf of Lions (NW Mediterranean): Meteorological and hydrodynamical forcing, Cont. Shelf Res., 28, 15, 19571970, 2008

Bourgeois, S., Pruski, A. M., Sun, M.-Y., Buscail, R., Lantoine, F., Kerhervé, P., Vétion, G., Rivière, B., and Charles, F.: Distribution and lability of land-derived organic matter in the surface sediments of the Rhône prodelta and the adjacent shelf (Mediterranean Sea, France): a multi proxy study, Biogeosciences, 8, 3107-3125, doi:10.5194/bg-8-3107-2011, 2011.

Canals, M., Puig, P., Durrieu de Madron, X., Heussner, S., Palanques, A., and Fabres, J.: Flushing submarine canyons, Nature, 444, 354-357, 2006.

Danovaro, R.: Methods for the Study of Deep-Sea Sediments, Their Functioning and Biodiversity, CRC Press, Boca Raton, US, 428 pp. 2010.

Danovaro, R., Dinet, A., Duineveld, G., and Tselepides, A.: Benthic response to particulate fluxes in different trophic environments: a comparison between the Gulf of Lions-Catalan Sea (westernMediterranean) and the Cretan Sea (eastern-Mediterranean), Prog. Oceanogr., 44, 287-312, 1999.

Danovaro, R., Dell'Anno, A., Fabiano, M., Pusceddu, A., and Tselepides, A.: Deep-sea ecosystem response to climate changes: the eastern Mediterranean case study, Trends Ecol. Evol., 16, 505510, 2001.

Danovaro, R., Bianchelli, S., Gambi, C., Mea, M., and Zeppilli, D.: $\alpha$-, $\beta$-, $\gamma$-, $\delta$ - and $\varepsilon$-diversity of deep-sea nematodes in canyons 
and open slopes of Northeast Atlantic and Mediterranean margins, Mar. Ecol.-Prog. Ser., 396, 197-209, 2009.

Dauwe, B., Middelburg, J. J., Van-Rijswijk, P., Sinke, J., Herman, P. M. J., and Heip, C. H. R.: Enzymatically hydrolyzable amino acids in North Sea sediments and their possible implication for sediment nutritional values, J. Mar. Res., 57, 109-134, 1999.

Dell'Anno, A., Fabiano, M., Mei, M. L., and Danovaro, R.: Enzymatically hydrolysed protein and carbohydrates pools in deepsea sediments: estimates of the bioavailable fraction and methodological considerations, Mar. Ecol.-Prog. Ser., 196, 15-23, 2000.

Dell'Anno, A., Mei, M.L., Pusceddu, A., and Danovaro, R.: Assessing the trophic state and eutrophication of coastal marine systems: a new approach based on the biochemical composition of sediment organic matter, Mar. Pollut. Bull., 44, 611-622, 2002.

Dell'Anno, A., Pusceddu, A., Corinaldesi, C., Canals, M., Heussner, S., and Danovaro, R.: Trophic state of deep-sea sediments of continental margins: a biomimetic approach, Biogeosciences, in press, 2013.

Druffel, E. R. M. and Robinson, B. H.: Is the Deep-Sea on a Diet?, Science: 284. 5417, 1139-1140, 1999. Estrada, M.: Primary production in the northwestern Mediterranean, Sci. Mar., 60, 55-64, 1996.

Estrada, M.: Primary production in the northwestern Mediterranean, Sci. Mar., 60, 55-64, 1996.

Fabiano, M. and Pusceddu, A.: Total and hydrolizable particulate organic matter (carbohydrates, proteins and lipids) at a coastal station in Terra Nova Bay (Ross Sea, Antarctica), Polar Biol., 19, 125-132, 1998.

Fabiano, M., Danovaro, R., and Fraschetti, S.: A three-year time series of elemental and biochemical composition of organic matter in subtidal sandy sediments of the Ligurian Sea (northwestern Mediterranean), Cont. Shelf Res., 15, 1453-1469, 1995.

Fabres, J., Calafat, A., Canals, M., Barcena, M. A., and Flores, J. A.: Bransfield Basin fine-grained sediments: late-Holocene sedimentary processes and Antarctic oceanographic conditions, Holocene, 10, 703-718, 2000.

Fabres, J., Tesi, T., Velez, J., Batista, F., Lee, C., Calafat, A., Heussner, S., Palanques, A., and Miserocchi, S.: Seasonal and eventcontrolled export of organic matter from the shelf towards the Gulf of Lions continental slope, Cont. Shelf Res., 28, 19711983, 2008.

Gage, J. D. and Tyler, P. A.,: Deep-Sea Biology: A Natural History of Organisms at the Deep-Sea Floor, Cambridge University Press, Cambridge, 504, 1991.

Gardner, W. D., Richardson, M. J., Hinga, K. R., and Biscaye, P. E.: Resuspension measured with sediment traps in a high-energy environment, Earth Planet. Sci. Lett., 66, 262-278, 1983.

Gerchacov, S. M. and Hatcher, P. G.: Improved technique for analysis of carbohydrates in sediment, Limnol. Oceanogr., 17, 938943, 1972.

Glover, G., Gooday, A. J,. Bailey, D. M,. Billett, D. S. M, Chevaldonné, P., Colaço, A., Copley, J., Cuvelier, D., Desbruyères, D., Kalogeropoulou, V., Klages, M., Lampadariou, N., Lejeusne, C., Mestre, N. C., Paterson, G. L. J., Perez, T., Ruhl, H., Sarrazin, J., Soltwedel, T., Soto, E. H., Thatje, S., Tselepides, A., Van Gaever, S., and Vanreusel, A.: Chapter One: Temporal Change in DeepSea Benthic Ecosystems: A Review of the Evidence From Recent Time-Series Studies, Adv. Mar. Biol., 58, 1-95, 2010
Grémare, A., Amouroux, J. M., Charles, F., Dinet, A., RiauxGobin, C., Baudart, J., Medernach, L., Bodiou, J. Y., Vétion, G., Colomines, J. C., and Albert, P.: Temporal changes in the biochemical composition and nutritional value of the particulate organic matter available to surface deposit-feeders: a 2-year study, Mar. Ecol.-Prog. Ser. 150, 195-206, 1997.

Grémare, A. , Amouroux, J.-M., Charles, F., Medernach, L., Jordana, E., Nozais, C., Vétion, G., and Colomines, J.-C.: Temporal changes in the biochemical composition of particulate organic matter sedimentation in the Bay of Banyuls-sur-Mer, Oceanol. Acta, 21, 783-792, 1998.

Grémare, A., Medernach, L., deBovée, F., Amouroux, J. M., Vétion, G., and Albert, P.: Relationships between sedimentary organics and benthic meiofauna on the continental shelf and the upper slope of the Gulf of Lions (NW Mediterranean), Mar. Ecol.-Prog. Ser., 234, 85-94, 2002.

Grémare, A., Medernach, L. , deBovée, F., Amouroux, J. M. , Charles, F. , Dinet, A., Vétion, G., Albert, P., and Colomines, J. C.: Relationship between sedimentary organic matter and benthic fauna within the Gulf of Lion: synthesis on the identification of new biochemical descriptors of sedimentary organic nutritional value, Oceanol. Acta, 26, 391-406, 2003.

Grémare, A., Gutíerrez, D., Anschutz, P., Amouroux, J. M., Deflandre, B., and Vétion, G.: Spatio temporal changes in totally and enzymatically hydrolyzable amino acids of superficial sediments from three contrasted areas, Prog. Oceanogr., 65, 89-111, 2005.

Harris, P. T. and Whiteway, T.: Global distribution of large submarine canyons: Geomorphic differences between active and passive continental margins, Mar. Geol., 285, 69-86, 2011.

Hedges, J. I., Baldock, J. A., Gélinas, Y., Lee, C., Peterson, M., and Wakeham, S. G.: Evidence for non-selective preservation of organic matter in sinking marine particles, Nature, 409, 801-804, 2001.

Lastras, G., Canals, M., Amblas, D., Lavoie, C., Church, I., De Mol, B., Duran, R., Calafat, A. M., Hughes-Clarke, J. E., Smith, C. J., and Heussner, S.: Understanding sediment dynamics of two large submarine valleys from seafloor data: Blanes and La Fonera canyons, northwestern Mediterranean Sea, Mar. Geol., 280, 2039, 2011.

Lee, I. H. Lien, R. C., Liu, J. T., and Chuang, W. :Turbulent mixing and internal tides in Gaoping (Kaoping) Submarine Canyon, Taiwan, J. Marine Syst., 76, 383-396, 2009.

Levin, L. A. and Dayton, P. K.: Ecological theory and continental margins: where shallow meets deep, Trends Ecol. Evol., 24, 606617, 2009.

López-Fernández, P., Calafat, A. M., Sanchez-Vidal, A. S., Cateura, J., Company, J. B., Flexas, M. M., and Canals, M.: Multiple drivers of particle fluxes in the Blanes submarine canyon and adjacent open slope: results of a year round experiment, Prog. Oceanogr., submitted, 2013.

Lorenzen, C. J. and Jeffrey, S. W.: Determination of chlorophyll in seawater: report of intercalibration tests, UNESCO Technical Papers in Marine Science, 35, 1-20, 1980.

Marsh, J. B. and Wenstein, D. B.: A simple charring method for determination of lipids, J. Lipid Res., 7, 574-576, 1966.

Martín, J., Palanques, A., and Puig, P.: Composition and variability of downward particulate matter fluxes in the Palamós submarine canyon (NW Mediterranean), J. Marine Syst., 60, 75-97, 2006. 
Mayer, L. M.: The inertness of being organic, Mar. Chem. 92, 135140, 2004.

Mayer, L. M., Schick, L. L., Sawyer, T., Plante, C. J., Jumars, P. A., and Self, R. L.: Bioavailable amino acids in sediments: a biomimetic, kinetics-based approach, Limnol. Oceanogr., 40, 511-520, 1995.

McArdle, B. H. and Anderson, M. J.: Fitting multivariate models to community data: a comment on distance-based redundancy analysis, Ecology, 82, 290-297, 2001.

Medernach, L. M., Grémare, A., Amouroux, J. M., Colomines, J. C., and Vétion, G.: Temporal changes in the amino acid contents of particulate organic matter sedimenting in the Bay of Banyuls-surMer (northwestern Mediterranean), Mar. Ecol.-Prog. Ser., 214, 55-65, 2001.

Misic, C. and Covazzi-Harriague, A.: Organic matter recycling in a shallow coastal zone (NW Mediterranean): The influence of local and global climatic forcing and organic matter lability on hydrolytic enzyme activity, Cont. Shelf Res., 28, 2725-2735, 2008.

Monaco, A., Durrieu de Madron, X., Radakovitch, O., Heussner, S., and Carbonne, J.: Origin and variability of downward biogeochemical fluxes on the Rhone continental margin (NW mediterranean), Deep-Sea Res. Pt. I, 46, 1483-1511, 1999.

Mullenbach, B. L., Nittrouer, C. A., and Puig, P.: Sediment deposition in a modern submarine canyon: Eel Canyon, northern California, Mar. Geol., 211, 101-119, 2004.

Murray, J. W.: The oceans, International Geophysics, 50, 175-211, 1992.

Owens, S. A., Buesseler, K. O., Lamborg, C. H., Valdes, J., Lomas, M. W., Johnson, R. J., Steinberg, D. K., and Siegel, D. A.: A new time series of particle export from neutrally buoyant sediments traps at the Bermuda Atlantic Time-series Study site, Deep-Sea Res. Pt. I, 72, 34-47, 2013.

Palanques, A., Durrieu de Madron, X., Puig, P., Fabres, J., Guillén, J., Calafat, A., Canals, M., and Bonnin, J.: Suspended sediment fluxes and transport processes in the Gulf of Lions submarine canyons. The role of storms and dense water cascading, Mar. Geol., 234, 43-61, 2006.

Palanques, A., Guillén, J., Puig, P., and Durrieu de Madron, X.: Storm-driven shelf-to-canyon suspended sediment transport at the southwestern Gulf of Lions, Cont. Shelf Res., 28, 1947-1956, 2008.

Palanques, A., Puig, P., Durrieu de Madron, X., Sanchez-Vidal, A., Pasqual, C., Martın, J., Calafat, A., Heussner, S., and Canals, M.: Sediment transport to the deep canyons and open-slope of the Western Gulf of Lions during the 2006 intense cascading and open-sea convection period, Prog. Oceanogr., 16, 1-15, 2012.

Pasqual, C., Sanchez-Vidal, A., Zúñiga, D., Calafat, A., Canals, M., Durrieu de Madron, X., Puig, P., Heussner, S., Palanques, A., and Delsaut, N.: Flux and composition of settling particles across the continental margin of the Gulf of Lion: the role of dense shelf water cascading, Biogeosciences, 7, 217-231, doi:10.5194/bg-7217-2010, 2010.

Pasqual, C., Lee, C., Goñi, M., Tesi, T., Sanchez-Vidal, A., Calafat, A., Canals, M., and Heussner, S.: Use of organic biomarkers to trace the transport of marine and terrigenous organic matter through the southwestern canyons of the Gulf of Lion, Mar. Chem., 126, 1-12, 2011.

Pinckney, J., Papa, R., and Zingmark, R.: Comparison of highperformance liquid chromatographic, spectrophotometric, and fluorometric methods for determining chlorophyll a concentrations in estaurine sediments, J. Microbiol. Meth., 19, 59-66, 1994.

Puig, P. and Palanques, A.: Temporal variability and composition of settling particle fluxes on the Barcelona continental margin (northwestern Mediterranean), J. Mar. Res., 56, 639-654, 1998.

Pulido-Villena, E., Wagener, T., and Guieu, C.: Bacterial response to dust pulses in the western Mediterranean: Implications for carbon cycling in the oligotrophic ocean, Global Biogeochem. Cy., 22, GB1020, doi:10.1029/2007GB003091, 2008.

Pusceddu, A., Dell'Anno, A., and Fabiano, M.: Organic matter composition in coastal sediments at Terra Nova Bay (Ross Sea) during summer 1995, Polar Biol., 23, 288-293, 2000.

Pusceddu, A., Dell'Anno, A., Danovaro, R., Manini, E., Sarà, G., and Fabiano, M.: Enzymatically hydrolyzable protein and carbohydrate sedimentary pools as indicators of the trophic state of 'detritus sink' systems: a case study in a Mediterranean coastal lagoon, Estuaries, 26, 641-650, 2003.

Pusceddu, A., Dell'Anno, A., Fabiano, M., and Danovaro, R.: Quantity, biochemical composition and bioavailability of sediment organic matter as complementary signatures of benthic trophic status, Mar. Ecol.-Prog. Ser., 375, 41-52, 2009.

Pusceddu, A., Bianchelli, S., Canals, M., Sanchez-Vidal, A., Durrieu De Madron, X., Heussner, S., Lykousis, V., de Stigter, H., Trincardi, F., and Danovaro, R.: Organic matter in sediments of canyons and open slopes of the Portuguese, Catalan, Southern Adriatic and Cretan Sea margins, Deep-Sea Res. Pt. I, 57, 441457, 2010a.

Pusceddu, A., Mea, M., Gambi, C., Bianchelli, S., Canals, M., Sanchez-Vidal, A., Calafat, A., Heussner, S., Durrieu De Madron, X., Avril, J., Thomsen, L., Garcìa, R., and Danovaro R.: Ecosystem effects of dense water formation on deep Mediterranean ecosystems: an overview, Adv. Oceanogr. Limnol., 1, 6784, 2010b.

Pusceddu, A., Mea, M., Canals, M., Heussner, S., Durrieu de Madron, X., Sanchez-Vidal, A., Bianchelli, S., Corinaldesi, C., Dell'Anno, A., Thomsen, L., and Danovaro, R.: Major consequences of an intense dense shelf water cascading event on deep-sea benthic trophic conditions and meiofaunal biodiversity, Biogeosciences, 10, 2659-2670, doi:10.5194/bg-10-2659-2013, 2013.

Pyke, G. H., Pulliam, H. R., and Charnov, E. L.: Optimal foraging: a selective review of theory and tests, Quarterly Rev. Biol., 52, 137-154, 1977.

Rice, D. L.: The detritus nitrogen problem: new observations and perspectives from organic geochemistry, Mar. Ecol.-Progr. Ser., 9, 153-162, 1982.

Rossi, S., Grémare, A., Gili, J., Amouroux, J., Jordana, E., and Vétion, G.: Biochemical characteristics of settling particulate organic matter at two north-western Mediterranean sites: a seasonal comparison, Estuar. Coast. Shelf S., 58, 423-434, 2003.

Rovira, A. and Batalla, R. J.: Temporal distribution of suspended sediment transport in a Mediterranean basin: The lower Tordera (NE SPAIN), Geomorphology, 79, 58-71, 2006

Sanchez-Vidal, A., Pasqual, C., Kerherve, P., Heussner, S., Calafat, A., Palanques, A., Durrieu de Madron, X., Canals, M., and Puig, P.: Across margin export of organic matter by cascading events traced by stable isotopes, northwestern Mediterranean Sea, Limnol. Oceanogr., 54, 1488-1500, 2009. 
Sanchez-Vidal, A., Canals, M., Calafat, A.M., Lastras, G., PedrosaPàmies, R., Menéndez, M., Medina, R., Company, J. B., Hereu, B., Romero, J., and Alcovero, T.: Impacts on the deep-sea ecosystem by a severe coastal storm, PLoS ONE 7, e30395, doi:10.1371/journal.pone.0030395, 2012.

Shoener, T. W.: Theory of feeding strategies, Ann. Rev. Ecol. Syst., 11, 369-404, 1971,

Smith, C. R., De Leo, F.C., Bernardino, A. F., Sweetman, A. K., and Martinez Arbizu, P.: Abyssal food limitation, ecosystem structure and climate change, Trends Ecol. Evol., 23, 518-528, 2008.

Smith, K. L., Ruhl, H. A., Bett, B. J., Billett, D. S. M., Lampitt, R. S., and Kaufmann, R. S.: Climate, carbon cycling and deepocean ecosystems, P. Nat. Acad. Sci. USA, 106, 19211-19218, 2009.

Soetaert, K. and Van Oevelen, D.: Modeling Food Web Interactions in Benthic Deep-Sea Ecosystems, Oceanography, 22, 1, 128$143,2010$.

Szymczak-Zyla, M. and Kowalewska, G.: Chloropigments ad in the Gulf of Gdansk (Baltic Sea) as markers of the state of this environment, Mar. Pollut. Bull., 55, 512-528, 2007.

Taylor, G. T., Karl, D. M., and Pace, M. L.: Impact of bacteria and zooflagellates on the composition of sinking particles: an in situ experiment, Mar. Ecol.-Prog. Ser., 29, 141-155. 1986.

Tesi, T., Langone, L., Goñi, M. A., Turchetto, M., Miserocchi, S., and Boldrin, A.: Source and composition of organic matter in the Bari canyon (Italy): dense water cascading versus particulate export from the upper ocean, Deep-Sea Res. I, 55, 813-831, 2008.

Van Oevelen, D., Soetaert, K., Novoa, R.G., de Stigter, H., Cunha, M. R., Pusceddu, A., and Danovaro, R.: Canyon conditions impact carbon flows in food webs of three sections of the Nazare canyon, Deep-Sea Res. Pt. II, 58, 2461-2476, 2011.

Vandewiele, S. , Cowie, G., Soetaert, K., and Middelburg, J. J.: Amino acid biogeochemistry and organic matter degradation state across the Pakistan margin oxygen minimum zone, DeepSea Res. II, 56, 318-334, 2009.
Wakeham, S. G., Freeman, K. H., Pease, T. K., and Hayes, J. M.: A photoautotrophic source for lycopane in marine water columns, Geochim. Cosmochim. Ac., 57, 159-165, 1993.

Wakeham, S. G., Hedges, J. I., Lee, C., Peterson, M. L., and Hernes, P. J.: Compositions and transport of lipid biomarkers through the water column and surficial sediments of the equatorial Pacific Ocean, Deep-Sea Res. Pt. II, 44, 2131-2162, 1997.

Walsh, J. J.: Importance of continental margins in the marine biogeochemical cycling of carbon and nitrogen, Nature, 350, 53-55, 1991.

Weaver, P., Billett, D. S. M., Boetius, A., Danovaro, R., Freiwald, A., and Sibuet, M.: Hotspot ecosystem Research on the Margins of European Seas, Oceanography, 17, 132-144, 2004.

Witbaard, R., Duineveld, G. C. A., Van der Weele, J. A., Berghuis, E. M., and Reyss, J. P.: The benthic response to the seasonal deposition of phytopigments at the Porcupine Abyssal Plain in the North East Atlantic, Prog. Oceanogr., 43, 15-31, 2000.

Zúñiga, D., Calafat, A., Heussner, S., Miserocchi, S., SanchezVidal, A., Garcia-Orellana, J., Canals, M., Sanchez-Cabeza, J.A., Carbonne, J., Delsaut, N., and Saragoni, G.: Compositional and temporal evolution of particle fluxes in the open Algero-Balearic basin (Western Mediterranean), J. Marine Syst., 70, 196-214, 2008.

Zúñiga, D., Flexas, M.M., Sanchez-Vidal, A., Coenjaerts, J., Calafat, A., Jordi, G., García-Orellana, J., Puigdefábregas, J., Canals, M., Espino, M., Sardá, F. and Company, J. B.: Particle fluxes dynamics in Blanes submarine canyon (Northwestern Mediterranean), Prog. Oceanogr., 82, 239-251, 2009. 